\title{
Evaluasi pembelajaran tata nilai budaya Yogyakarta di taman kanak-kanak se-kabupaten bantul Yogyakarta
}

\author{
Sudaryanti, Joko Pamungkas, Harun, Amir Syamsudin \\ Pendidikan Guru Pendidikan Anak Usia Dini, FIP, Universitas Negeri Yogyakarta \\ Jalan Colombo No 1 Yogyakarta, Indonesia \\ E-mail: sudaryanti@uny.ac.id
}

\begin{tabular}{ll}
\hline \hline ARTICLE INFO & ABSTRACT \\
\hline \hline Article & Tujuan penelitian ini yaitu untuk mendeskripsikan proses pembelajaran dan \\
history: & mengelompokkan capaian perkembangan anak tentang tata nilai moral \& sosial \\
Received: $09-10-2019$ & emosional anak usia dini di Taman Kanak-kanak wilayah Kabupaten Bantul. \\
Revised: $09-11-2019$ & Rancangan evaluasi terdiri dari deskripsi proses pembelajaran tata nilai \\
Accepted:18-12-2019 & kemasyarakatan dan tata nilai moral di Taman Kanak-kanak, penilaian capaian \\
& perkembangan anak, dan pengelompokan capaian perkembangan tata nilai moral \\
Keywords: & dan sosial emosional anak. Temuan penelitian adalah 53\% guru TK sudah \\
nilai moral, sosial & melakukan proses pembelajaran yang menyenangkan bagi anak, dan 43.2\% \\
emosional, pembelajaran, & capaian perkembangan anak sudah melampaui standar capaian perkembangan \\
anak usia dini & tata nilai moral dan sosial emosional anak.
\end{tabular}

\begin{abstract}
The purpose of this study is to describe the learning process and classify the achievement of children's development of moral \& sosial-emotional values of early childhood in kindergarten in Bantul Regency. The evaluation design consists of a description of the learning process of sosial values and moral values in kindergarten, assessment of children's development achievements, and grouping of the achievements of children's moral \& sosial-emotional values. The findings of the study were $53 \%$ of kindergarten teachers had made a fun learning process for children, and $43.2 \%$ of children's development achievements had exceeded the standard achievement of the development of children's moral \& sosial-emotional values.
\end{abstract}

\section{PENDAHULUAN}

Tata krama pergaulan sosial tercermin dalam keluarga, pendidikan, hukum, agama, ekonomi, birokrasi, dan organisasi kemasyarakatan. Individu berperan sesuai dengan kedudukan yang dimainkannya dalam lembaga-lembaga tersebut. Pola pergaulan dalam keluarga, dan lembaga pendidikan yang sarat dengan etika dan moral atau tata krama perlu diteliti (Soehardi, 1997). Tata krama sangat berperan penting untuk mepermudah manusia untuk diterima di lingkungan masyarakat sekitar. Peran orang tua sangatlah penting dalam pembentukan karakter anak terutama dalam menerapkan sikap tata krama atau sopan santun anak. Saat ini perilaku anak lebih cenderung kehilangan etika dan sopan santun. Berdasarkan obeservasi yang dilakukan di beberapa sekolah dasar di Semarang ditemui beberapa sikap yang mencerminkan kurangnya tata krama siswa di sekolah (Shaula, D.F \& Hasyim, N., 2017).

Kegelisahan orang tua terhadap tata krama anak milenial merupakan transisi nilai dari generasi tua ke generasi muda. Orang tua memakai standar norma zamannya, sedangkan anak juga memakai standar norma zamannya pula. Nilai-nilai budaya universal merupakan jembatan yang mempetemukan antara tata nilai generasi tua dengan generasi muda. Peraturan Daerah nomor 4 tahun 2011 tentang tata nilai budaya Yogyakarta merupakan nilai universal yang mewadahi sekaligus menyelaraskan nilai-nilai kesantunan pergaulan sosial dalam lingkup kelurga, sekolah, maupun masyarakat. 


\section{METODE}

Jenis penelitian adalah evaluasi pembelajaran tata nilai kemasyarakatan dan tata nilai moral anak usia dini di Kabupaten Bantul Yogyakarta. Rancangan evaluasi terdiri dari deskripsi proses pembelajaran tata nilai kemasyarakatan dan tata nilai moral di Taman Kanak-kanak, penilaian capaian perkembangan anak tentang nilai kemasyarakatan dan tata nilai moral, dan pengelompokan capaian perkembangan anak.

Subjek penelitian dipilih berdasarkan kriteria: (1) anak usia 4-6 tahun yang belajar di Taman kanak-kanak terakreditasi A, (2) dengan pengampu guru PAUD bersertifikat minimal 1 tahun, dan (3) memiliki visi dan misi pelestarian budaya/kearifan lokal/tata nilai budaya Yogyakarta. Berdasarkan 3 kriteria tersebut ditemukanlah 22 orang guru TK dan 472 anak usia TK di wilayah Bantul. Teknik pengambilan data dengan cara observasi proses pembelajaran, observasi capaian tata nilai kemasyarakatan dan tata nilai moral, serta wawancara dengan guru pengampu. Teknik analisis data menggunakan pendekatan kualitatif, yaitu pemaparan data, pemisahan data, pengelompokkan data, dan penyimpulan data dalam bentuk kategori capaian perkembangan anak.

\section{HASIL DAN PEMBAHASAN}

Hasil

Tata nilai budaya Yogyakarta (Perda DIY Nomor 4 Tahun 2011, BAB III, Pasal 4) meliputi tata nilai religio-spriritual, tata nilai moral, tata nilai kemasyarakatan, tata nilai adat dan tradisi, tata nilai pendidikan dan pengetahuan, tata nilai teknologi, tata nilai penataan ruang dan arsitektur, tata nilai mata pencaharian, tata nilai kesenian, tata nilai Bahasa, tata nilai benda cagar budaya dan kawasan cagar budaya, tata nilai kepemimpinan dan pemerintahan, tata nilai kejuangan dan kebangsaan, dan tata nilai semangat keyogyakartaan.

Dokumen tata nilai Yogyakarta dimaksudkan sebagai pedoman dalam bertingkah laku semua warga masyarakat DIY dan acuan penyusunan aturan hukum daerah guna melestarikan nilai-nilai budaya Jawa dalam setiap aspek kehidupan bermasyarakat, termasuk dalam bidang pendidikan anak usia dini di wilayah Yogyakarta. Fokus kajian ini adalah tata nilai kemasyarakatan dan tata nilai moral anak usia dini dalam konteks pembelajaran anak melakukan (learning by doing) di lingkungan Taman Kanak-kanak Kabupaten Bantul.

Keselarasan antara ucapan dan perbuatan manusia menjadi kunci harmoni sosial. Hubungan manusia dengan manusia lain, alam semesta, dan Tuhan secara selaras merupakan inti dari moralitas. Ucapan yang benar menghasilkan kejujuran. Kejujuran memberi dampak kebaikan kepada semua. Ada kepastian norma, yaitu siapa yang berkata dan berbuat dengan benar pasti selamat, sebaliknya siapa yang berkata dan berbuat salah pasti hancur. Ketentuan ini berlaku untuk semua manusia tanpa embelembel kasta sosial. Penjelasan rinci tentang tata nilai moral sebagai berikut.

“...Dunia ini berputar dan berubah, begitu pula dengan nasib manusia juga berubah-ubah, berputar, berganti (cakramanggilingan). Oleh karena itu manusia jangan mudah takjub dengan kesementaraan perubahan yang memukau (aja gumunan, aja kagetan), dan jangan pula menyombongkan diri dan meremehkan orang lain dikala dirinya berjaya sementara orang lain sedang sengsara (aja dumeh). Boleh jadi suatu saat nanti status sosial seseorang atau keturunan orang yang status sosialnya tinggi menjadi sengsara, sementara orang kecil atau keturunan orang yang berstatus sosial rendah malahan bisa berjaya (tunggak jarak mrajak, tunggak jati mati). Manusia harus berhati-hati dalam bertindak, jangan sampai melukai dan atau merugikan pihak lain. Setiap perbuatan yang dilakukan pasti akan berbuah akibat yang diterima oleh pelakunya (ngundhuh wohing pakarti). Perbuatan baik akan berbuah kebajikan, perbuatan buruk akan berbuah keburukan (sapa kang nandur bakal ngundhuh, sapa kang gawé bakal nganggo, sapa kang utang bakal nyaur)".

Watak mulia dapat diusahakan dengan menjauhkan anak dari perangai angkuh, bengis, jahil, serakah, pencurian, gila hormat, kesombongan karena pandai, memiliki harta banyak, kecantikan, keberanian, suka menantang untuk bertengkar, tidak tahu malu, iri hati, dengki, dan suka mencela orang lain. Guru harus senantiasa berusaha menanam kebajikan dan terus-menerus menyemai budi luhur sebagai keutamaan. Orang yang baik selalu berusaha menyenangkan hati orang lain seperti 
mengemukakan pendirian secara lembut, berhati-hati dalam berbicara, tingkah dan tutur katanya bersahaja, setiap ucapannya terasa sejuk menembus kalbu karena dilandasi nurani yang bersih, bertenggang rasa dan berbelas kasih kepada semua makhluk hidup. Ringkasnya, semua makhluk menjadiberbahagia karena pergaulan sosialnya.

Tata nilai kemasyarakatan dilandasi nilai kasih sayang diantara anggota masyarakat. Kerukunan merupakan akar pokok hidup bermasyarakat, karena kerukunan memberikan kekuatan, dan pertikaian mendatangkan kehancuran. Apabila ada perbedaan pemikiran, maka dapat diselesaikan secara musyawarah dan mufakat. Apabila ada pertengkaran diantara anggota masyarakat, maka batasilah pertengkaran itu hanya pada orang-orang yang terlibat saja, dan tidak mengundang anggota lain untuk mendukung satu kelompok dan menolak kelompok lainnya. Pertikaian sebaiknya diselesaikan dengan cara rendah hati, yang menang tidak perlu mengejek yang kalah, yang kalah tetap perlu dijaga harga diri dan martabatanya. Pergaulan sosial yang harmoni mempersyaratkan saling berbagi ilmu dan pengalaman, saling mengasihi, dan saling membimbing satu sama lain.

“...Hidup bersama dalam masyarakat dituntut adanya solidaritas atau kesetiakawanan sosial antar anggota masyarakat, baik dalam keadaan senang maupun susah (sabaya mati, sabaya mukti). Satu sama lain harus tolong-menolong, bantu-membantu, sehingga setiap permasalahan yang timbul dapat dihadapi dan diselesaikan secara lebih ringan dan memadai. Terlebih lagi, dalam menangani urusan yang berkaitan dengan kepentingan bersama, antar anggota masyarakat hendaknya seiasekata, bekerja sama, bergotong-royong bahu-membahu (saiyek saéka kapti) merampungkan urusan bersama dengan sebaik-baiknya. Bahkan, demi kepentingan umum, orang janganlah berhitung-hitung akan imbalan bagi pekerjaan yang dilakukannya (sepi ing pamrih, ramé ing gawé) karena bekerja demi kepentingan umum itu merupakan wujud keutamaan tugas yang harus diemban manusia sebagai makhluk Tuhan dalam rangka memperindah dan menjaga kelestarian dunia (hamemayu hayuning bawana), agar dunia senantiasa dapat memberi perasaan aman dan damai (ayom ayem) bagi penghuninya".

Kohesi dan harmoni sosial akan terjadi dengan baik apabila dilandasi prinsip hormat. Penghormatan diberikan berdasarkan urutan prioritas, yaitu kepada kedua orang tua, mertua lelaki dan perempuan, saudara tua, guru, kepada pemimpin atau atasan. Sejalan dengan prinsip memanusiakan orang itu ialah prinsip empati dan timbal-balik. Empati merupakan prinsip yang menempatkan diri sendiri pada diri orang lain sehingga orang akan berhati-hati dan bertindak adil kepada orang lain karena dalam diri orang lain itu bersemayam pula dirinya yang akan ikut merasakan akibat tindakannya.

“...Prinsip hormat yang lebih bersifat batiniah itu diekspresikan secara lahiriah dalam wujud sopan santun (tata krama; unggah-ungguh). Sopan santun itu menjauhkan orang dari celaan (tata krama iku ngadohaké ing panyendhu). Dalam pergaulan orang harus pandai mengemas dirinya dengan bahasa, busana, dan gerak-gerik anggota tubuh secara santun dan sedapat mungkin menyenangkan hati orang di sekitarnya. Agar dapat membawa diri dengan tepat dalam pergaulan, orang harus pula dengan cermat menyesuaikan ketiga kemasan tadi dengan waktu, tempat, dan konteks (angon mangsa, empan papan, duga prayoga). Dasar terdalam dari semua itu ialah sikap batin yang harus dijaga bahwa menghormat itu bukanlah wujud kerendahdirian melainkan wujud kerendahatian".

Kajian tentang penerapan tata nilai budaya Yogyakarta diantaranya tulisan Moch Riza Zakaria (2017) yang fokus pada tata nilai berbahasa Jawa. Pendekatan yang dipakai ialah akulturasi tata nilai dalam kehidupan masyarakat, dan seiring tuntutan zaman berubah menjadi aturan formal yang disepakati dan disahkan legislatif. Demikian juga tulisan Nuryani Tri Rahayu dkk (2014) tentang model pewarisan nilai-nilai budaya Jawa melalui pemanfaatan upacara ritual. Temuan dari penelitian ini ialah perubahan sikap subjek yang diteliti ke arah perilaku positif. Tulisan Sukmawan Wisnu Pradanta dkk (2015) tentang kajian nilai-nilai budaya Jawa dalam tradisi bancaan weton di kota Surakarta yang mengajarkan toleransi, keseimbangan hubungan manusia dengan Tuhan sebagai wujud ketaatan manusia kepada sang Pencipta. 


\section{Pembahasan}

Pembelajaran tata nilai moral \& tata nilai sosial di Taman Kanak-kanak diekspresikan dalam bentuk perilaku guru menyapa anak dengan lembut, memperhatikan kebutuhan belajar anak dengan cermat, menjelaskan kegiatan bermain dengan runtut, membimbing kesulitan belajar anak dengan sabar, melerai anak yang bertengkar dengan adil, membujuk dengan santun anak yang sedang marah, memberi contoh berpakaian yang sopan, menghargai pendapat anak, membujuk dengan lemah lembut anak yang saling ejek untuk saling memaafkan, dan memanggil anak sesuai nama panggilannya.

Subjek guru yang diobservasi sebanyak 42 orang guru, dan tersebar di tujuh Taman Kanakkanak. Perilaku guru menyapa anak dengan lembut dilakukan oleh semua guru dengan rentang keramahan mulai dari baik sampai dengan sempurna. Keramahan guru dalam menyapa anak pada kategori baik sebanyak 26.2\%, sangat baik sebanyak 28.6\%, dan sempurna sebanyak 45.2\%. Demikian pula, guru memperhatikan kebutuhan belajar anak dengan cermat sudah dilakukan oleh semua guru dengan rentang kecermatan antara baik sampai dengan sempurna. Kecermatan guru dalam memperhatikan kebutuhan anak dapat dikategorikan menjadi baik sebanyak 33.3\%, sangat baik sebanyak $42.9 \%$, dan sempurna sebanyak $23.8 \%$.

Guru menjelaskan kegiatan bermain dengan runtut. Keruntutan guru dalam menjelaskan dapat direntang mulai dari baik sampai dengan sempurna. Keruntutuan penjelasan guru dapat dikategorikan menjadi baik sebanyak $38.1 \%$, sangat baik sebanyak $33.3 \%$, dan sempurna sebanyak 28,6\%. Demikian pula perilaku guru membimbing kesulitan belajar anak dengan sabar sudah dilakukan oleh guru. Rentang kesabaran guru mulai dari kategori baik sampai dengan sempurna. Guru yang sabar membimbing anak dapat dikategorikan baik sebanyak $26.2 \%$, sangat baik sebanyak $26.2 \%$, dan sempurna sebanyak $47.6 \%$.

Guru melerai anak yang bertengkar dengan adil. Keadilan guru sudah ditunjukkan oleh semua guru yang diobservasi. Rentang keadilan guru dapat dikategorikan menjadi baik sebanyak 19\%, sangat baik $45.2 \%$, dan sempurna 35.7\%. Begitu pula guru membujuk dengan santun anak yang sedang marah sudah dilakukan semua guru. Rentang kepandaian membujuk guru dapat dikategorikan menjadi baik sebanyak $28.6 \%$, sangat baik sebanyak $33.3 \%$, dan sempurna sebanyak $38.1 \%$.

Guru memberi contoh berpakaian yang sopan sudah dilakukan oleh semua guru. Rentang kesopanan berpakaian guru dapat dikategorikan menjadi baik sebanyak 42.9\%, sangat baik sebanyak $21.4 \%$, dan sempurna sebanyak $35.7 \%$. Disamping itu, guru juga menghargai pendapat anak. Rentang guru menghargai pendapat anak dapat dikategorikan menjadi baik sebanyak $31 \%$, sangat baik sebanyak $40.5 \%$, dan sempurna sebanyak $28.6 \%$.

Guru membujuk dengan lembah lembut anak yang saling ejek untuk saling memaafkan. Perilaku ini dilakukan oleh semua guru yang diobservasi. Rentang kelemahlembutan bujukan guru dapat dikategorikan menjadi baik sebanyak $35.7 \%$, sangat baik sebanyak $33.3 \%$, dan sempurna sebanyak $31 \%$. Adapun perilaku guru memanggil anak sesuai nama panggilannya, juga sudah dilakukan oleh semua guru yang diobservasi. Rentang kelupaan menyebut nama panggilan anak dapat dikategorikan menjadi baik sebanyak $28.6 \%$, sangat baik sebanyak $38.1 \%$, dan sempurna sebanyak $33.3 \%$.

Berdasarkan data tersebut ada tiga kategori tata nilai moral \& tata nilai sosial pembelajaran yang dilakukan oleh guru di lembaga PAUD, yaitu perilaku keruntutuan penjelasan kegiatan kepada anak, kesantunan berpakaian, dan kelemahlembutan dalam membujuk anak untuk saling memaafkan dapat dikategorikan baik. Perilaku cermat terhadap kebutuhan belajar anak, keadilan dalam melerai pertengkaran antar anak, penghargaan terhadap pendapat anak, dan pemanggilan anak dengan namanya dapat dikategorikan sangat baik. Sedangkan perilaku kehangatan dalam menyapa anak, kesabaran membimbing kesulitan belajar anak, dan kesantunan membujuk anak yang marah dapat dikategorikan sempurna. 
Tabel 1.

Kelas Interval Kategori Tata Nilai Moral \& Nilai Sosial Guru TK dan Capaian Perkembangan Moral \& Sosial Emosional Anak Usia Dini

\begin{tabular}{ccc}
\hline No & Kategori & Interval score \\
\hline 1 & Sempurna & $>86.875$ \\
\hline 2 & Sangat baik & $74.125-86.874$ \\
\hline 3 & Baik & $61.375-74.124$ \\
\hline 4 & Cukup & $48.625-61.374$ \\
\hline 5 & Kurang & $35.875-48.624$ \\
\hline 6 & Sangat kurang & $23.125-35.874$ \\
\hline 7 & Tidak sempurna & $<23.124$ \\
\hline
\end{tabular}

Tata nilai moral dan nilai sosial guruTaman Kanak-kanak secara keseluruhan dapat dideskripsikan skor dan frekuensinya seperti pada Tabel 2.

Tabel 2.

Tata Nilai Moral \& Nilai Sosial Emosional Guru Taman Kanak-kanak

\begin{tabular}{cccc}
\hline Score & Frequency & Percent & Cum. Percent \\
\hline 78.57 & 1 & 2.4 & 2.4 \\
\hline 81.43 & 2 & 4.8 & 7.1 \\
\hline 82.86 & 6 & 14.3 & 21.4 \\
\hline 84.29 & 6 & 14.3 & 35.7 \\
\hline 85.71 & 5 & 11.9 & 47.6 \\
\hline 87.14 & 8 & 19.0 & 66.7 \\
\hline 88.57 & 8 & 19.0 & 85.7 \\
\hline 90.00 & 3 & 7.1 & 92.9 \\
\hline 91.43 & 3 & 7.1 & 100.0 \\
\hline Total & 42 & 100.0 & \\
\hline
\end{tabular}

Sumber: Data Penelitian 2019

Apabila data Tabel 2 dibandingkan dengan kelas interval pada Tabel 1, maka ada 20 orang guru yang dikategorikan sangat baik (47\%), dan ada 22 orang guru yang dikategorikan sempurna (53\%) untuk tata nilai moral dan nilai sosialnya dalam proses pembelajaran di kelas.

Indikator capaian perkembangan nilai moral, dan sosial-emosional anak usia dini meliputi anak berpakaian yang sopan, memaafkan teman yang mengejeknya, meminta maaf ketika melakukan kesalahan kepada teman, mengalah ketika bertengkar dengan teman, menahan marah ketika diejek teman, menyuci tangan sebelum makan, menyuci tangan setelah makan, melakukan buang air besar secara mandiri, melakukan buang air kecil secara mandiri, membuang sampah pada tempatnya, antri untuk melakukan kegiatan tertentu, berbagi sesuatu dengan teman-temannya, bermain dengan temantemannya, menyapa teman-temannya dengan ceria, dan menolong temannya dengan tulus.

Anak berpakaian sopan menurut kadar kepantasan yang dipakaikan oleh orang tua dan diatur oleh internal sekolah masing-masing. Kesopanan berpakaian anak dapat dikategorikan menjadi baik sebanyak $32.6 \%$, sangat baik sebanyak $32.8 \%$, dan sempurna sebanyak $34.5 \%$. Anak memaafkan teman yang mengejeknya dapat dikategorikan menjadi baik sebanyak $34.3 \%$, sangat baik sebanyak, $37.3 \%$, dan sempurna sebanyak $28.4 \%$. Anak meminta maaf ketika melakukan kesalahan kepada teman dapat dikategorikan menjadi baik sebanyak 30.9\%, sangat baik sebanyak 36.7\%, dan sempurna sebanyak $32.4 \%$. Anak mengalah ketika bertengkar dengan teman dapat dikategorikan menjadi baik sebanyak $35.4 \%$, sangata baik sebanyak $32.2 \%$, dan sempurna sebanyak $32.4 \%$. Anak menahan marah ketika diejek teman dapat dikategorikan menjadi baik sebanyak $35.2 \%$, sangat baik sebanyak $35.2 \%$, dan sempurna sebanyak $29.7 \%$.

Anak menyuci tangan sebelum makan dapat dikategorikan menjadi baik sebanyak $37.1 \%$, sangat baik sebanyak $32.4 \%$, dan sempurna sebanyak $30.5 \%$. Anak menyuci tangan setelah makandapat dikategorikan menjadi baik sebanyak $34.1 \%$, sangat baik sebanyak $31.4 \%$, dan sempurna sebanyak $34.5 \%$. Anak melakukan buang air besar secara mandiridapat dikategorikan menjadi baik sebanyak 
$31.6 \%$, sangat baik sebanyak 32.8\%, dan sempurna sebanyak 35.6\%. Anak melakukan buang air kecil secara mandiridapat dikategorikan menjadi baik sebanyak $35.8 \%$, sangat baik sebanyak $30.5 \%$, dan sempurna sebanyak $33.7 \%$.

Anak membuang sampah pada tempatnyadapat dikategorikan menjadi baik sebanyak $32.2 \%$, sangat baik sebanyak $31.1 \%$, dan sempurna sebanyak 36.7\%. Anak antri untuk melakukan kegiatan tertentudapat dikategorikan menjadi baik sebanyak 34.5\%, sangat baik sebanyak $32.2 \%$, dan sempurna sebanyak $33.3 \%$. Anak berbagi sesuatu dengan teman-temannya dapat dikategorikan menjadi baik sebanyak $31.8 \%$, sangat baik sebanyak $37.1 \%$, dan sempurna sebanyak $31.1 \%$. Anak bermain dengan teman-temannyadapat dikategorikan menjadi baik sebanyak $35.6 \%$, sangat baik sebanyak $34.3 \%$, dan sempurna sebanyak $30.1 \%$. Anak menyapa teman-temannya dengan ceria dapat dikategorikan menjadi baik sebanyak $30.9 \%$, sangat baik sebanyak $30.9 \%$, dan sempurna sebanyak $38.1 \%$. Anak menolong temannya dengan tulus dapat dikategorikan menjadi baik sebanyak $32.2 \%$, sangat baik sebanyak $30.1 \%$, dan sempurna sebanyak $37.7 \%$.

Berdasarkan deskripsi data tersebut, capaian perkembangan nilai moral anak berpakaian yang sopan masuk dalam kategori sempurna, artinya mayoritas anak berpakaian sangat sopan. Capaian perkembangan nilai moral anak memaafkan teman yang mengejeknya, dan meminta maaf ketika melakukan kesalahan kepada teman masuk dalam kategori sangat baik. Adapun capaian perkembangan nilai moral anak mengalah ketika bertengkar dengan teman, dan menahan marah ketika diejek teman masuk dalam kategori baik.

Tabel 3.

Capaian Perkembangan Nilai Moral \& Sosial Emosional Anak Taman Kanak-kanak

\begin{tabular}{cccc}
\hline Score & Frequency & Percent & Cum. Percent \\
\hline 77.14 & 2 & 0.4 & 0.4 \\
\hline 79.05 & 9 & 1.9 & 2.3 \\
\hline 80.00 & 8 & 1.7 & 4.0 \\
\hline 80.95 & 13 & 2.8 & 6.8 \\
\hline 81.90 & 30 & 6.4 & 13.1 \\
\hline 82.86 & 28 & 5.9 & 19.1 \\
\hline 83.81 & 59 & 12.5 & 31.6 \\
\hline 84.76 & 61 & 12.9 & 44.5 \\
\hline 85.71 & 58 & 12.3 & 56.8 \\
\hline 86.67 & 68 & 14.4 & 71.2 \\
\hline 87.62 & 36 & 7.6 & 87.8 \\
\hline 88.57 & 43 & 9.1 & 93.6 \\
\hline 89.52 & 27 & 5.7 & 96.4 \\
\hline 90.48 & 13 & 2.8 & 98.7 \\
\hline 91.43 & 11 & 2.3 & 99.8 \\
\hline 92.38 & 5 & 1.1 & 100.0 \\
\hline 93.33 & 1 & 0.2 & \\
\hline Total & 472 & 100.0 & \\
\hline
\end{tabular}

Sumber: Data Penelitian 2019

Capaian perkembangan nilai sosial-emosional seperti anakmenyuci tangan setelah makan, melakukan buang air besar secara mandiri, membuang sampah pada tempatnya, menyapa temantemannya dengan ceria, dan menolong temannya dengan tulus, masuk dalam kategori sempurna. Capaian perkembangan nilai sosial emosional seperti anak berbagi sesuatu dengan teman-temannya, masuk dalam kategori sangat baik. Capaian perkembangan nilai sosiaemosional seperti anak menyuci tangan sebelum makan, melakukan buang air kecil secara mandiri,antri untuk melakukan kegiatan tertentu, dan bermain dengan teman-temannya, masuk dalam kategori baik.

Apabila data capaian perkembangan nilai moral \& sosial-emosianal anak yang terdapat pada Tabel 3 dibandingkan dengan kelas interval pada Tabel 1, maka diperoleh simpulan bahwa $56.8 \%$ capaian perkembangan nilai moral \& sosial-emosional anak masuk dalam kategori sangat baik, dan $43.2 \%$ masuk dalam kategori sempurna. 


\section{PENUTUP}

Tata nilai moral dan nilai sosial dalam proses pembelajaran di kelas tercermin dalam perilaku guru yang mengekspreiskan kehangatan dalam menyapa anak, kesabaran dalam membimbing kesulitan belajar anak, dan kesantunan membujuk anak yang marah. Perilaku positif dalam proses pembelajaran ini ditunjukkan oleh 53\% guru TK yang diobservasi.

Capaian perkembangan nilai moral \& sosial emosional tercermin dalam perilaku anak menyuci tangan setelah makan, melakukan buang air besar secara mandiri, membuang sampah pada tempatnya, menyapa teman-temannya dengan ceria, dan menolong temannya dengan tulus. Capaian perkembangan nilai moral \& sosial emosional yang sangat ideal ini ditunjukkan oleh $43.2 \%$ anak yang diobservasi.

\section{UCAPAN TERIMAKASIH}

Tim Peneliti Research Group mengucakan terima kasih kepada Fakultas Ilmu Pendidikan Universitas Negeri Yogyakarta yang telah menyetujui kontrak penelitian kelompok dosen ini.

\section{DAFTARPUSTAKA}

Nuryani, T.R, Setyarto, Efendi, A. (2014). Model pewarisan nilai-nilai budaya Jawa melalui pemanfaatan upacara ritual. Jurnal Ilmu Komunikasi. Volume 12, Nomor 1, Januari - April 2014, halaman 55-69.

Peraturan Daerah Provinsi Daerah Istimewa Yogyakarta Nomor 4 Tahun 2011 tentang tata nilai budaya Yogyakarta.

Shaula, D.F \& Hasyim, N. (2017). Menanamkan konsep tata krama pada anak melalui perancangan game edukasi. Jurnal informatika Upgris Vol. 3, No. 1, (2017) P/E-ISSN: 2460-4801/24476645, DOI: 10.26877/jiu.v3i1.1609.

Soehardi. (1997). Pengembangan tata krama dalam rangka pembinaan nilai budaya. Humaniora. VI, Oktober-November 1997. https://doi.org/10.22146/jh.v0i6.1870.

Sukmawan Wisnu Pradanta, Bani Sudardi, Slamet Subiyantoro. (2015). Kajian nilai-nilai budaya Jawa dalam tradisi bancaan weton di kota Surakarta: sebuah kajian simbolisme dalam budaya Jawa. Lingua, Vol. 12, No. 2, September 2015.

Zakaria. M.R (2017). Penerapan tata nilai budaya Yogyakarta melalui bahasa jawa berdasarkan peraturan daerah DIY nomor 4 tahun 2011 tentang tata nilai budaya Yogyakarta. Skripsi. UIN Sunan Kalijaga Yogyakarta. 